\title{
Cosmetic potentials of physic nut (Jatropha curcas Linn.) seed oil: A review
}

\author{
Warra, A. A. \\ Department of Biochemistry, Kebbi State University of Science and Technology, \\ P.M.B. 1144, Aliero, Nigeria. Author E-mail : aliyuwarra@yahoo.com, \\ Tel: +2348076297326, +2347031280900
}

\begin{abstract}
The present review justify the potentials of Jatropha curcas $L$. seed oil and its uses in cosmetic production. The values of physicochemical properties and other parameters of the oil determined are in favour of its usage for cosmetics based on the previous research works. Exploitation of its seed oil for use in cosmetic products in some countries were also critically reviewed. Most details centered on the most profitable use of the seed oil compared to its usage for biofuels.
\end{abstract}

Keywords: Jatropha, seed oil value, cosmetics, soap making.

\section{INTRODUCTION}

Jatropha curcas L. or physic nut is a drought resistant large shrub or small tree, belonging to the genus Euphorbiaceae, producing oil containing seeds (Jongschaap et al, 2007). Jatropha curcas L. is the commonest specie found in Nigeria, but many species exist in different parts of the world. Heller,(1996) reported about $165-175$ species that were known from the genus Jatropha Bhagat and Kulkarni(nd) report 14 wild and cultivated species in India. This against 12 species reported by Krishnan and Paramathma,(2009).It is a multipurpose, drought resistant tree and can be cultivated in areas of low rainfall (Pratt et al, 2002). Jatropha is suitable for quick and efficient domestication compared with other woody species (Achten, et al, 2010). Names used to describe the plant vary per region or country. It is most commonly known as 'Physic nut'. In Mali it is known as "Pourghere". In the Ivory Coast it is known as "bagani". In Senegal it is known as "tabanani". In Tanzania it is known as "makaen"/mmbono" (Fact Foundation, 2006). In Nigeria it is known as "binidazugu/cinidazugu" and "lapa lapa" in Hausa and Yoruba languages respectively. (Blench, 2007 and Blench, 2003). Unlike the major oil seed crops, there are currently no agronomically improved varieties available for $\mathrm{J}$. curcas. At present, the varieties being used to established plantations in Africa and Asia are inedible (King et al,2009) Due to its toxicity, J.curcas oil is not edible and is traditionally used for manufacturing soap and medicinal applications(Jongschaap et al, 2007). Due to the fact that the seeds of J.curcas contains some toxins compounds such as those reported by (King et al,2009) a protein (curcin) and phorbol-esters (diterpenoids), other researchers (Goel, et al,2007) suggested that the detoxification or complete removal of phorbol esters is essential before its use in industrial or medicinal applications. The major toxin phorbolester is not vulnerable to heat, but can be hydrolyzed to less toxic substances extractable by either water or ethanol. (Usman, et al, 2009). Aregheore et al. (2003) employed heat treatment, alkaline hydrolysis and solvent extraction for the detoxification of the Jatropha curcas seed cake. Despite the toxicity of J. curcas, edible varieties are known to exist in Mexico which are not currently being exploited. (King et al, 2009) Oil for soap making is the most profitable use; the fruit of Jatropha contain viscous oil that can be used for soap making. (Openshaw, 2000). It is rich in palmitic acid, with high levels of hydrophobicity, and makes a soft, durable soap under even the simplest of manufacturing processes. It is also used in West Africa, Zambia, Tanzania and Zimbabwe as a soapstock including the manufacture of soft laundry soap. (Pratt et al, 2002). Jatropha oil gives a very good foaming, white soap with positive effects on the skin, partly due to the glycerine content of the soap. (Henning, 2000). Jatropha soap is said to have medicinal characteristics and is therefore used by people with various skin diseases and sensitivity to regular soap.(Messenmaker,2008) The $36 \%$ linoleic acid (C18:2) content in Jatropha kernel oil is of possible interest for skin care. (Pratt et al, 2002);(Benge,2006) The oil has a strong purgative 
action and is also widely used for skin diseases and to soothe pain such as that caused by rheumatism (Henning, 2003). The seed oil can be applied to treat eczema (Heller, 1996). The oil is also an ingredient in hair conditioners( Brittaine and Lutaladio,2010)The use of Jatropha for soap industry,( alternative Karitee Butter) and cosmetics is regarded as one of its nonenergy use.(Rijssenbeek,2007)
This paper attempts to review the prospects and potentials of Jatropha curcas $L$. seed oil in skin care production, the current state of research, and the work underway for the promotion of indigenous cultivation of the plant and the oil extraction substantial enough for commercial scale skin care production.

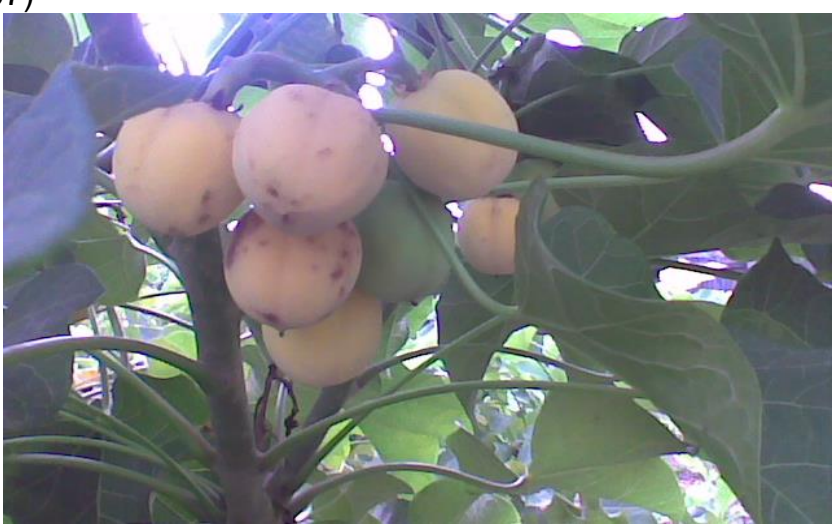

Fig 1. Jatropha curcas L plant with fruits (riped) grown in Northern part of Nigeria.

( Warra,2010)

Fig 2. Dried Seeds of Jatropha Curcas L

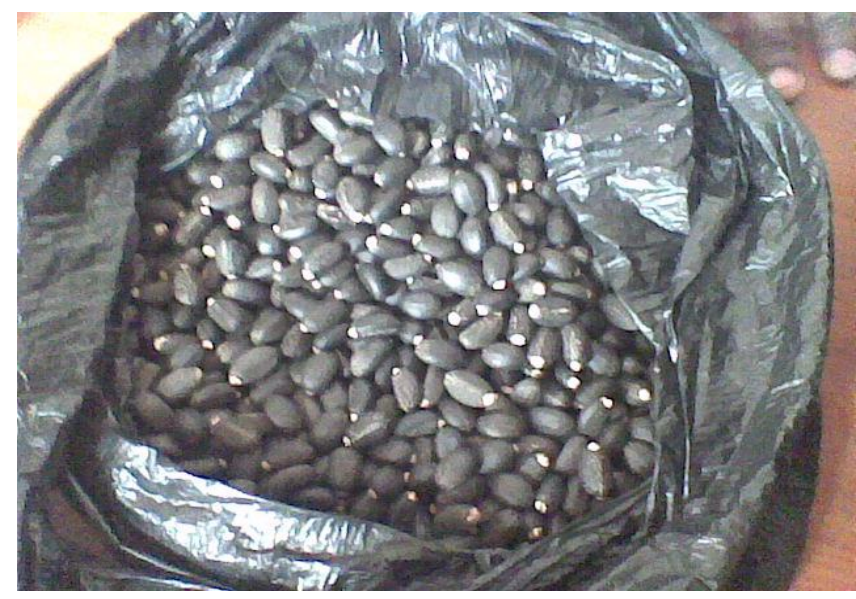

The origin of Jatropha curcas and the Countries that are prominent in growing the plant: Jatropha curcas originates from central America and was distributed by Portuguese seafarers via the cape Verde Islands to countries in Africa and Asia .(Hernning,2003)Jatropha is widely grown in Mexico,Nicaragua, N.E.Thailand and in parts of India. It is now promoted in Sourthern Africa, Brazil, Mali and Nepal. J. curcas was chosen as one of the prime plant oil species, especially for Brazil, Nepal and
Fig 3. Fresh seeds of Jatropha curcas $L$

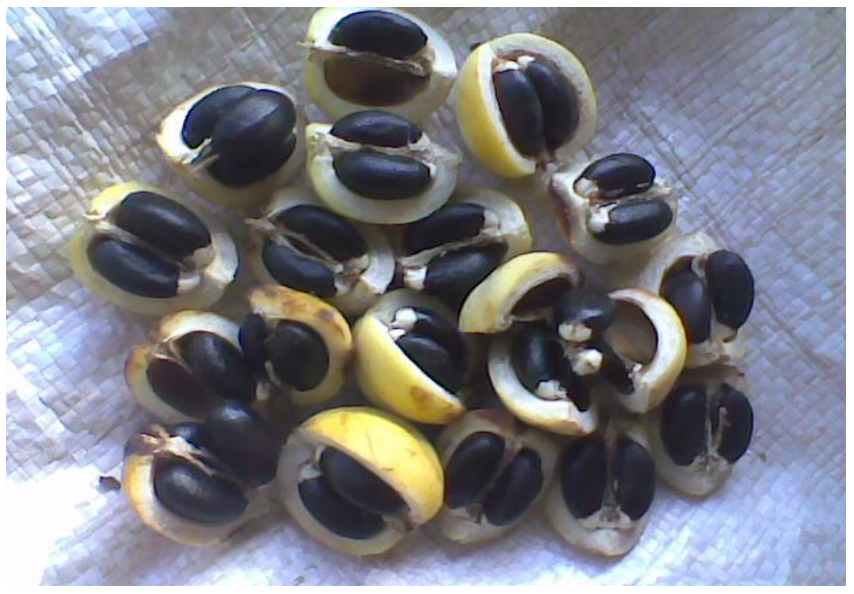

Zimbabwe. Areas of these three countries, that already were growing such species, were chosen as demonstration sites for the utilization of plant oil with appropriate technology. (Openshaw, 2000)

Chemical structure: Jatropha seed oil chemically consists of triacylglycerol with linear fatty acid chain(unbranched) with/without double bonds. 
Am. J. Sci. Ind. Res., 2012, 3(6): 358-366

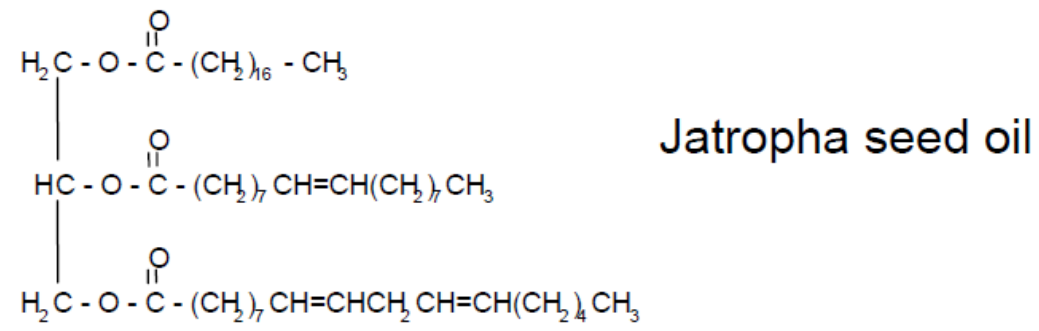

\section{Diterpenoids content in jatropha curcas $L$.}

Interestingly, two forms of diterpenoids which are classes of terpenoids having aromatic qualities are found in this plant, The diterpenoid Curcuson A and the diterpenoid Curcuson C. ( Director General Department of Alternative Energy And Efficiency Royal Government of Thailand, nd). This is a great prospect for the plant in perfumes and other cosmetics industries.

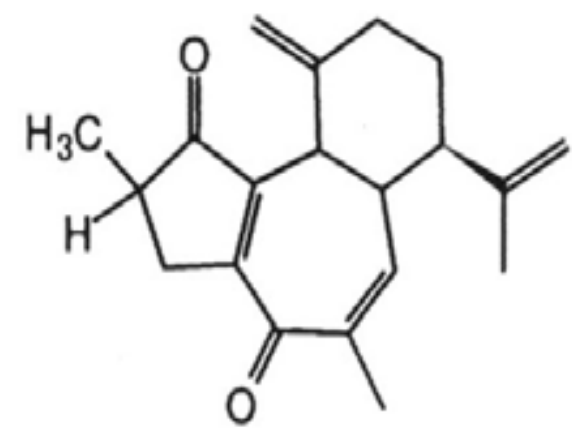

\section{Curcuson A}

\section{The diterpenoid Curcuson A}

Oil extraction and content: Extracting oil from Jatropha seeds can be done either with a manual press, such as the ram press, or with a mechanical press, such as the oil expeller.

With mechanic expellers (like sundhara press) up to $75-80 \%$ of oil can be extracted. With hand press like the Bielenberg ram press only $60-65 \%$ of the oil can be extracted (5kg of seeds give about 1 litre of oil (Henning, 2003). For research purposes, Sayyar et al (2009) in their research on optimization and kinetics in the extraction of oil from Jatropha found Hexane to be the best solvent for the process as compared to petroleum ether.

The oil content determined by Akbar, et al ( 2009) from Malaysian Jatropha seed kernels using Hexane was $63.16 \%$. High oil content of Jatropha Curcas indicated that Jatropha Curcas are suitable as nonedible vegetable oil feedstock in oleochemical industries ( biodiesel, fatty acids, soap, fatty nitrogenous derivatives, surfactants and detergents.(

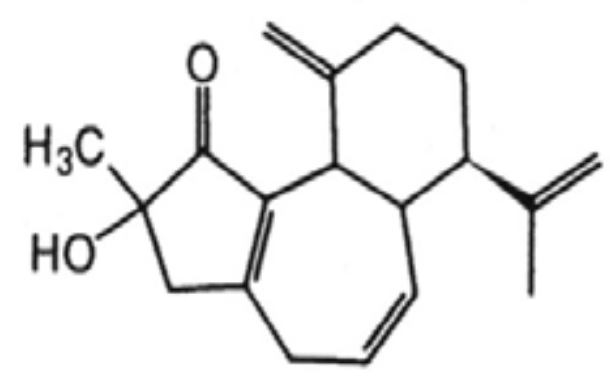

\section{Curcuson C}

\section{The diterpenoid Curcuson C}

Akbar, et al , 2009). Adebowale and Adedire (2006) reported a high oil content (64.4\%),dominant triacylglycerol lipid specie(88.2\%) and an appreciable percentage( $47.3 \%$ ) of linoleic acid after extraction from samples of Jatropha curcas seeds obtained from markets in five different towns in Nigeria (Table 1 and 2)

Table 1. Percentage oil composition and lipid classes of Jatropha curcas.

\begin{tabular}{|l|c|}
\hline Composition & Percentage \\
\hline Oil & 66.4 \\
Unsaponifiable & 3.8 \\
Hydrocarbons/sytereo esters & 4.8 \\
Triacycerols & 88.2 \\
Free fatty acid & 3.4 \\
Diacylglycerols & 2.5 \\
Sterols & 2.2 \\
Monoacyglycerols & 1.7 \\
Polar lipids & 2.0 \\
\hline
\end{tabular}

Source: Adebowale and Adedire (2006 
Table 2. Fatty acid composition of Jatropha curcas.

\begin{tabular}{|l|l|}
\hline Composition & Percentage \\
\hline Palmitic acid (C16:0) & 11.3 \\
Stearic acid (C18:0) & 17.0 \\
Oleic acid (C18:1) & 12.8 \\
Linoleic cid (C18:2) & 47.3 \\
Arachidic acid (C20:0) & 4.7 \\
Arachidoleic acid (C20:1) & 1.8 \\
Behenic acid ( C22:0) & 0.6 \\
C24:0 & 44 \\
\hline
\end{tabular}

Source: Adebowale and Adedire (2006)

The physicochemical characteristics of Jatropha curcas L. seed oil in favour of utilization for cosmetics: To determine the industrial value of a particular oil or fat which is dependent on composition and purity, a number of chemical tests are carried out to have quality control over fats and oils used as raw materials for the production of soaps and other cosmetics.

These analytical methods includes saponification value and iodine value determination, the former gives an idea of the amount of alkali needed for converting a definite amount of fat or oil into soap and in detecting the adulteration of a fat or oil by one of lower or higher saponification value while the latter helps in finding the adulteration in a fat or oil and judging its suitability for making soap and other cosmetics .Another analytical method used for fats and oils analysis is the Acid value determination which gives the extent of rancidity of the stored oil or fat sample, thereby deciding on its suitability for cosmetic production.
Table 1 shows some physicochemical properties of the Malaysian J. curcas seed oil compared to the Nigerian $J$. curcas seed oil (Salimon and Abdullah,2008 and Akintayo,2004) The parameters measured and the values obtained are in favour of utilization of the Jatropha curcas seed oil for soap production. The lodine values $(\mathrm{mg} / \mathrm{g}) 135.85+\ldots 1.44$ and 105.20+_0.70

are higher than the value $85.0 \quad \mathrm{I}_{2} / 100 \mathrm{~g}$ value of Cyprus esculents oil. High iodine value justify utilization in soap and shampoo productions.(Hassan, et al,2007) relatively similar to105.53 the mean value obtained for sesame cultivars grown in sudan (Sabah El khier,et al,2008),and120.46 obtained for Heeria insignis but higher than 21.59 for Isoberlinia doka which may find application as a raw material in industries for the manufacture of soap.(Kubmarawa et al,2007).

The acid values $(\mathrm{mg} \mathrm{KOH} / \mathrm{g}) 1.50+\_0.07$ and $3.50+0.10$ are relatively comparable with $4 \mathrm{mg} / \mathrm{KOH}$ /g recommended by a Cordex Alimenterius commission for ground nuts ( Abayeh et al, 1998 ) and(1.84) reported for sesame seed oil (Almustapha et al, 1995 ) which are used in soap making. The saponification values $(\mathrm{mg} / \mathrm{g}) \quad 208.50+0.47$ and $198.85+1.40$ are relatively comparable with $213 \mathrm{mgKOH} / \mathrm{g}$ in neem seed oil(Akpan,1999) and $185.00 \mathrm{mgKOH} / \mathrm{g}$ in Cyperus esculentus oil(Hassan et al,2007) which are also oils used in soap making. High saponification value indicated that the oil is normal triglyceride ( triacylglycerol) and very useful in production of liquid soap and shampoo industries.( Akbar, et al,2009)

Table 3. Physicochemical characteristic of Malaysian J.curcas seed oil and Nigeria J.curcas L seed oil

\begin{tabular}{|l|l|l|}
\hline Parameter & \multicolumn{2}{|c|}{ Values } \\
\hline & Malaysia & Nigeria \\
\hline lodine value $(\mathbf{m g} / \mathbf{g})$ & $135.85+\_1.44$ & $105.20+0.70$ \\
\hline Acid value $(\mathrm{mg} \mathrm{KOH} / \mathrm{g})$ & $1.50+\_0.07$ & $3.50+0.10$ \\
\hline Saponification value(mg/g) & $208.50+\_0.47$ & $198.85+\_1.40$ \\
\hline
\end{tabular}

Source: Akintayo 2004 
Countries where Jatropha curcas seed oil have been used for soap production: In many countries, Jatropha oil is known for its usage for soap making. It has been used commercially for soap manufacture for decades, both by large and small soap producers.

In former times Portugal imported Jatropha seeds from Cape Verde Islands to produce soap.(Fact Foundation,2006). In India, Nepal and Zimbabwe the prize of tallow or the prize of Jatropha and other plant oils is at least 2.5 times the selling prize of diesel. Obviously, selling Jatropha oil for soap making is far more profitable in these countries than using it as a diesel or kerosene substitute. (Openshaw, 2000).

In Mali soap making process is very labour intensive, producing small amounts of relatively poor-quality soap. When Jatropha oil is used, either alone or in combination with other local plant oils such as shea butter, large amounts of more refined soap are produced.(Henning,nd). Some details of the economy of soap production in Mali with the means of the Bielenberg hand press are shown in Table 4. In other countries the Jatropha activities also show positive economic results, as far as soap making is concerned (Henning,2004).In the years around 1940 ,Madagascar was exporting Jatropha seeds to Marseille, France, as a raw material for soap production. ('Savon de Marseille") (Henning,nd). In senegal, a project was carried out by ATI (now Enterprise works) an American NGO, in the region of Ties, Planted Jatropha hedges and extracted Jatropha oil with ram press. The oil was used to run Diesel engines (for flour mills) and to make soap. (Henning,nd). Jatropha soap is perceived in Malawi as a 'medicated soap'. The soap from unrefined oil is considered, like neem-based soap, to be an effective, gentle anti- scabies wash.(Pratt et al,2002)

The only product of Jatropha tree, which has penetrated market in Tanzania so far, is Jatropha soap.

Jatropha seedlings, cuttings, seeds and oil transactions are still confined between seeds collectors, oil extractors and soap makers. It has been noted that the final consumers of Jatropha soap are people with skin diseases and those who are allergic to toilet and perfumed soaps. (Manyanya, nd)

In GUANTANAMO, Cuba - Farming families in El Oro community, located in the semi-arid region of this eastern Cuban province, have been successful in making soap from the extracted oil from the Jatropha curcas tree (known locally as 'piñón botija'). The plantation of the Jatropha curcas covers some 2.5 hectares, and for now the soap is produced by hand from the Jatropha nut, or physic nut, in a small laboratory. Every $100 \mathrm{~kg}$ of crushed nuts produces an estimated 38 litres of oil. "The machine is still in its test phase, but with that quantity of oil we can make around 50 bars of soap," ( Director General Department of Alternative Energy And Efficiency Royal Government of Thailand, nd).

In Zambia, mainly in the areas near the border to Mozambique, large quantities of Jatropha hedges exist. Generally the population neglects the use of the seeds. The hedges serve as a protection device against cattle. In Lusaka a 2 ha test plantation exists, which was planted by the NCSR (Nations Council of Scientific Research), by contract with a soap production firm. The intention was to replace imported tallow with Jatropha oil. .( Director General Department of Alternative Energy And Efficiency Royal Government of Thailand, nd).

Even if the current boom for Jatropha production is based mainly on the incentive of producing biofuel, the possible range of products which can be derived from jatropha is much broader (Grass,2009). Hence base on expert estimates for 39 countries, from the range of possible uses of jatropha based products is the utilization of the seed oil for cosmetics and soap. (GEXSI, 2008). 
Am. J. Sci. Ind. Res., 2012, 3(6): 358-366

Table 4: Economy of soap production in Mali (Henning,nd)

\begin{tabular}{|c|c|c|c|c|}
\hline Description & Quantity & Unit & $\begin{array}{l}\text { Price per Unity } \\
\text { US\$ }\end{array}$ & Amount in US\$ \\
\hline Seeds (give 3 I of oil with handpres) & 12 & $\mathrm{Kg}$ & 0,1 & 1,20 \\
\hline Caustic soda & 0,5 & $\mathrm{Kg}$ & 1,2 & 0,60 \\
\hline $\begin{array}{l}\text { Labour (4h for pressing, } 1 \mathrm{~h} \text { soap } \\
\text { production) }\end{array}$ & 5 & $\mathrm{Kg}$ & 0,2 & 1,00 \\
\hline Depreciation/maintainance & (5yrs, 10t/a,240,-) & $\mathrm{H}$ & 0,02 & 0,24 \\
\hline Total expenses & & & & 3,04 \\
\hline \multicolumn{5}{|l|}{ Revenues } \\
\hline Presscake & 9 & $\mathrm{~kg}$ & 0,03 & 0,27 \\
\hline White soap & 28 & Pieces (170 kg) & 0,15 & 4,20 \\
\hline Total revenues & & & & 4,47 \\
\hline Net Profit & & & & 1,43 \\
\hline Profit per liter of oil & & & 0,48 & \\
\hline Profit per $\mathrm{kg}$ of soap & & & 0,31 & \\
\hline Price per kg of soap & & & 0,89 & \\
\hline
\end{tabular}

Figure 3: Use of Jatropha products

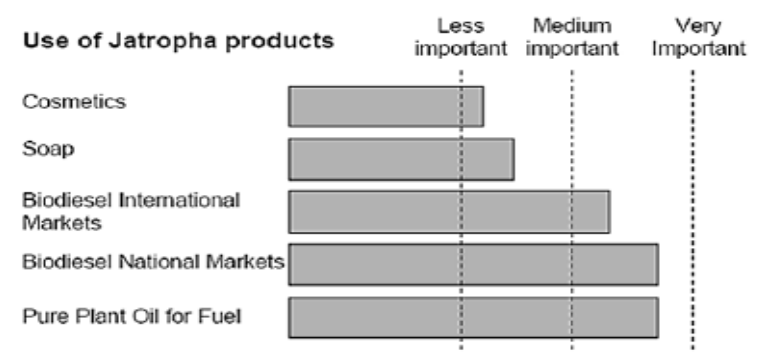

Source: GEXSI (2008) based on expert estimates for 39 countries

Exploitation of Jatropha (Gubitz, et al, 1998).

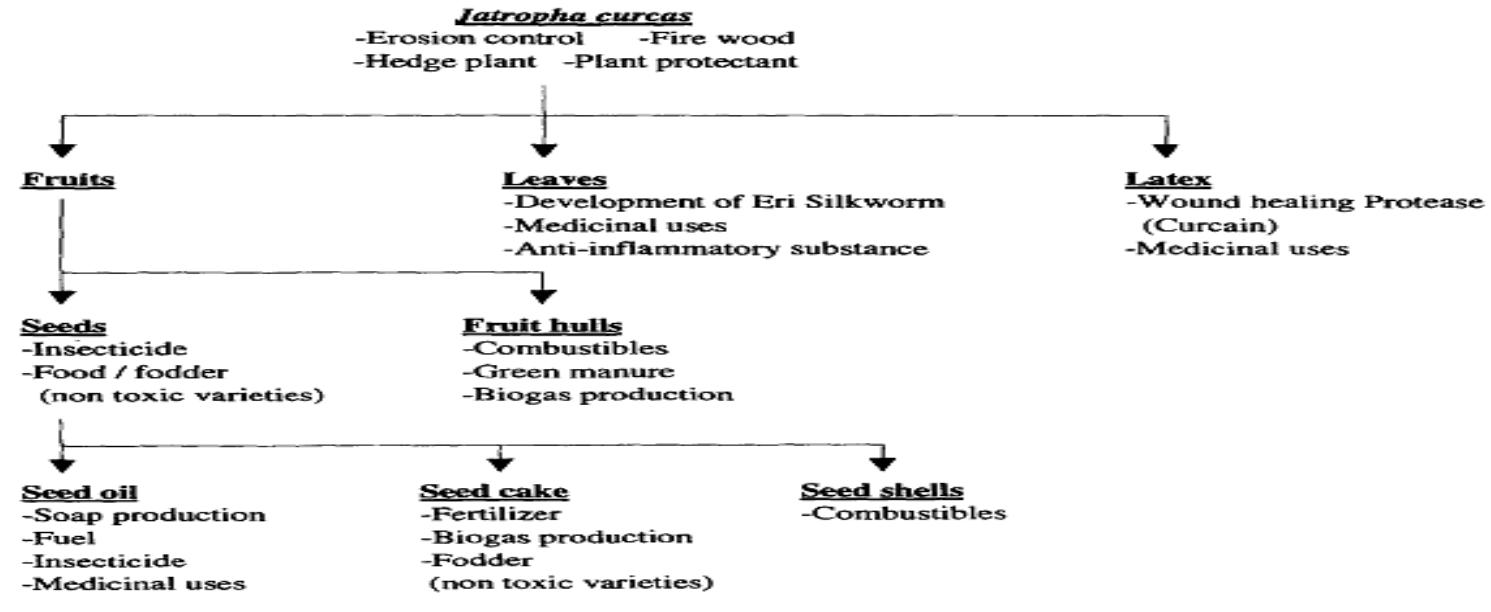


The case of the GTZ project in Mali will be used to demonstrate the economic benefits of physic nut cultivation. The Jatropha system is based on existing hedges that were used to fence in fields and to control erosion. The project promotes this system by creating a market for physic nut products.. The oil is a raw material for soap production that generates income to local women producers. (Heller,1996). The GTZ project found soap production to be quite profitable. Three litres of oil could be extracted from $12 \mathrm{~kg}$ of jatropha seed, producing $4.7 \mathrm{~kg}$ of soap worth USD 4.20 and $9 \mathrm{~kg}$ of seed cake worth USD 0.27 . Factoring in the cost of seeds, caustic soda and labour which totalled USD 3.04, it still resulted in a profit of USD 1.43 that could be made from five hours work (Henning, 2004).

Jatropha soap is made by adding a solution of sodium hydroxide (caustic soda) to jatropha oil. This simple technology has turned soap making into a viable small-scale rural enterprise appropriate to many rural areas of developing countries. Jatropha soap is valued as a medicinal soap for treating skin ailments. On the one hand, making jatropha soap can be highly profitable, with $4.7 \mathrm{~kg}$ of soap produced from 13 litres of jatropha oil in only five hours (Henning, 2004).

Kakute Ltd, one of the Tanzanian organizations promoting jatropha for oil production, erosion control and soap making, conducted an evaluation in 2003 of the profitability of jatropha-related activities. It found soap making to be more profitable than oil extraction which, in turn, was more profitable than seed collection or production (see Table 5). Soap produced from jatropha is sold as a medical soap, effective in treating skin ailments. Henning (2004) noted that jatropha soap is sold in dispensaries at a higher price than other soaps on the market.

Fig 5: Profitability of other Jatropha- related Activities in comparism with soap making( Henning,2004)

\begin{tabular}{|l|l|}
\hline Activity & Return on labour USD per hour \\
\hline Collection and sale of Jatropha seeds & 0.29 \\
\hline Oil extraction & 1.09 \\
\hline Soap making & 2.82 \\
\hline
\end{tabular}

\section{CONCLUSION}

Considering the cosmetic uses of the plant oil, domestication of the plant to extract oil for use in cosmetic preparations should be encouraged. With current knowledge Jatropha curcas L. seed oil, at local level it could best used profitably for indigenous production of cosmetics particularly soap than its utilization for biofuel.

\section{REFERENCES}

Abayeh OJ, Aina EA and Okuonghae.1998.Oil content and oil quality characteristics of some Nigerian oil seeds. Journal of pure and Applied sciences Vol. 1 No.1 pp17- 23

Achten WMJ, Nielsen LR, Aerts R, Lengkeek AG.,Kjaer ED, Trabucco A, Hansen JK, Maes WH, Graudal LA, kinnifesi, FK. and Muys B,.2010. Towards domestication of Jatropha curcas. Biofuels Vol. 1 No.1 pp 91-107

Adebowale KO and Adedire CO.2006. Chemical composition and insecticidal properties of the underutilized Jatropha curcas seed oil. African Journal of Biotechnology Vol 5 No.10 pp 901-906.

Aderibigbe AO, Johnson COLE, Makkar HPS, Becker K, and Foidl, N. 1997.Chemical composition and effect of heat on organic matter and nitrogen degradability and some anti - nutritional components of Jatropha meal. Animal Feed Science and Technology. Vol. 67 pp 223-243.

Akbar E, Yaakob Z., Kamarudin SK, Ismail M, and Salimon J. 2009. Charecteristic and Composition of Jatropha Curcas Oil seed from Malaysia and its Potential as Biodiesel Feedstock. European Journal of Scientific Research.Vol. 29 No.3 pp 396-403

Akintayo ET. 2004.Characteristic and composition of Parkia biglobbossa and Jatropha curcas oils and cakes. Biosource Technology Vol. 92 pp307-310

Akpan UG. 1999. Extraction and characterization of neem seed oil: In: (Ed) Eyo, A.A, Aluko,P.O, Garba, S.A, Ali, U.D, Lamai, S.L and Olufeagba, S.O.2000. Biotechnology and Sus-tainable development in Nigeria, proceedings of the $12^{\text {th }}$ Annual conference of the Biotechnology Society of Nigeria, pp63-66. 
Almustafa DA, Bilbis LS, Rades JM, and Abubakar MK. 1995.Chemical composition of some oil seeds grown in Northern Nigeria. Nigerian Journal of Biochemistry and molecular Biology Vol.10 pp39-43

Benge M. 2006. Assessment of the potential of Jatropha curcas,(biodiesel tree) for energy production and other uses in developing countries. p8. Accessed at

http://www.ascensionpublishing.com/BIZ/jatropha.pdf 18/4/2010

Bhagat RB and Kulkarni DK. nd . Jatropha nana Dalz. \& Gibs.: A plant for future energy. Accessed at http://www.jatropha.de/documents/Jatropha_Manuscri pt_Kulkarni.pdf 27/4/2010

Blench, R. 2007. Hausa names for plants and trees. http://www.rogerblench.info/RBOP.htm

Printout December 11, 2007. Accessed at http://www.rogerblench.info/Ethnoscience\%

20data/Hausa\%20plant\%20names.pdf 11/5/2009

Blench, R.2003. Hausa names for plants and trees. Available at http://www.org/odi/staff/r. Printout August 5,2003

Brittaine R and Lutaladio N.2010. Jatropha: A Smallholder Bioenergy CropThe Potential for Pro-Poor Development. Integrated Crop Management Vol. 8 pp 67- 85

Director General Department of Alternative Energy and Efficiency Royal Government of Thailand. nd. The role of Jatropha Curcas in support of the Thai Government's National Policy for Bio Diesel. Accessed http://www.akha.org/content/environment/jatrophacurc asagriculturetoindustrythailand.pdf $\quad$ 25/5/2010

Fact Foundation. 2006. Hand book on Jatropha Curcas.First Draft. March 2006 .Accessed at

http://www.jatropha_platform.org/documents/Factoundation_jatropha_Handbook_March_2006.pdf. $1 / 6 / 2009$

GEXSI. 2008. Global Market Study on Jatropha. Final Report; prepared for the World Wide Fund for Nature(WWF).London/Berlin. Accessed at

http://www.jatropha.platform.org/downloads.htm

Goel G, Makkar HPS, Francis G and Becker K. 2007. Phorbol Esters: Structure, Biological Activity, and Toxicity in Animals. International Journal of Toxicology Vol.26 pp279 288

Grass M. 2009. Jatropha curcas L: Visions and Realities. Journal of Agriculture and Rural Development in the Tropics and subtropics. Vol. 110 No.1 pp29-38
Gubitz GM, Mittelbach M and Trabi M. 1999. Exploitation of the tropical seed plant Jatropha curcasL.,BioresourceTechnology Vol. 67 pp73-82.

Hassan LG, Osoba O, Umar KJ and Inuwa M. 2007. Physico- chemical Analysis of cyperus Esculentus oil. Yauri Journal of Arts and Science Vol.2 No.1pp 1-4.

Heller J. 1996 .Physic Nut. Jatropha curcas L. Promoting the conservation and use of underutilized and neglected crops. 1. Institute of Plant Genetics and Crop Plant Research, Gatersleben/International Plant GeneticResources Institute, Rome. ISBN 92-9043278-0.

Henning RK. 2004. "The Jatropha system" Integrated Rural Development by Utilization of Jatropha curcas L.(JCL) as Raw material and as Renewable Energy. Accessed at

http://www.jatropha.de/journal/The\%20jatropha\%20pa per\%june\%202004.pdf. 19/6/09

Henning RK.2003.The Jatropha Booklet: A guide to Jatropha Promotion in Africa. Bagani GbR.Weissensberg,Germany.p5-33.Accessed at http://www.jatropha.de/documents/jcl booklet_Africa.pdf 13/8/2009

Henning RK.2000.The Jatropha Manual:A guide to the integrated exploitation of the Jatropha plant in Zambia. Bagani GbR. Produced for GTZ. GTZ-ASIP-SupportProject Southern Province, Choma. Accessed at http://www.jatropha.de/documents/jcl-manual.pdf $8 / 3 / 2010$

Henning RK. nd. Fighting Desertification by Integrated Utilization of Jatropha plant: an integrated approach to supply energy and create income for rural development. Accessed at http://www.etfrn.org/etfrn/workshop/degradelands/docu ments/Jatropha_paper.pdf 1/6/2009

Jongschaap REE, Corre WJ, Bindraban PS and Brandenburg WA. 2007. Claims and Facts on jatropha curcas L : Global Jatropha curcas evaluation, breeding and propagation Programme. Plant Research International, B.V. Wageningen, The Netherlands. p1-

King AJ, He W, Cuevas JA, Freudenberger, Ramiaramanana D and Graham IA.2009. Potential of Jatropha curcas as a source of renewable oil and animal feed: Review paper. Journal of Experimental Botany.10.1093/jxb/erp025. Page 1-9 Downloaded from

http://jxb.oxfordjournas.org on 27 February, 2010

Krishnan PR and Paramathma M.2009. Potentials and Jatropha species wealth of India. Current Science. Vol.97 No.7 pp 1000-1004.

Kubmarawa D Barminas JT, Nwaigwe CN, Kidah MI and kekong D.2007.Transesterifi-cation of some vegetable 
oils for use as Biofuel. Journal of Chemical Society of Nigeria. Vol.32 No.2 pp77-80

Mayanya L. nd. Jatropha sub-sector in Tanzania. Accessedd at

http://www.jatropha.de/Journal/Jatropha520Developm ent\%20in\%20Tanzania.pdf 27/4/2010.

Messenmaker L. 2008. The Green Myth? Assessment of the Jatropha value chain and its potential for pro-poor biofuel development in Northern Tanzania. MSc thesis. International Development Studies (IDS) at the Faculty of Geosciences, Utrecht University, The Netherlands. p45. Accessed at

http://www.jatropha.de/documents/Messenmaker2008 ThegreenMyth-small.pdf 2/5/2010

Openshaw K. 2000. A review of Jatropha curcas: an oil plant of unfulfilled promise. Biomass and bioenergy Vol. 19 pp1-15

Pratt JH, Henry EMT, Mbeza HF, Mlaka E and Satali LB. 2002. Malawi Agroforestry Extension Project Marketing \& Enterprise Program. Main Report. Malawi Agroforestry Publication No.47 pp44-46

Rijssenbeek W. 2007. Jatropha Global Position.Workshop EU Brussels. RR Energy for FACT Foundation. p37 Accessed at http://ec.uropa.en/research/agriculture/pdf/events/jator pha_en.pdf 18/4/2010

Sabah El-khier, Ishaq, K.E.A and Yagoub,A.E.A(2008).Chemical composition and oil Characteristics of sesame cultivars grown in Sudan. Research Journal of Agriculture And Biological sciences. Vol.4 No.6 pp761-766

Salimon $J$ and Abdullah R. 2008 .Physicochemical properties of Malaysian Jatropha curcas Seed oil. Sains Malaysiana. Vol. 37 No. 4 pp379-382

Sayyar S, Zainal Abidin Z, Yunus R and Muhammad A. 2009. Extraction of oil from Jatropha seedsOptimization and Kinetics. American Journal of Applied Sciences. Vol. 6 No.7pp1390-1395 Science Publications.

Usman LA, Ameen OM, Lawal A and Awolola GV. 2009. Effect of alkaline hydrolysis on the quantity of extractable protein fractions (prolamin, albumin,globulin and glutelin) in Jatropha curcas seed cake. African Journal of Biotechnology. Vol. 8 No.22 pp 6374-6378.

Warra, A.A.( 2010). A review of Jatropha curcas L. as a potential source of oil for soap making. Proceedings of the $2^{\text {nd }} R M R D C$ International Conference on Natural Resources Development and Utilization. Abuja, Nigeria. Pp173-179 